\title{
A note on the infection of Scomberomorus brasiliensis (Osteichthyes, Scombridae) by Kudoa sp. (Myxozoa: Multivalvulida)
}

\author{
Eiras, JC. ${ }^{a, b *}$, Lima, JTAX.c, Cruz, CF ${ }^{a, b}$ and Saraiva, A. ${ }^{a, b}$

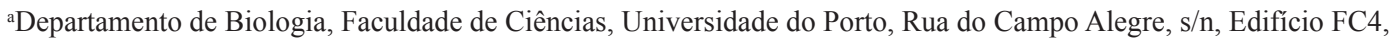 \\ 4169-007, Porto, Portugal

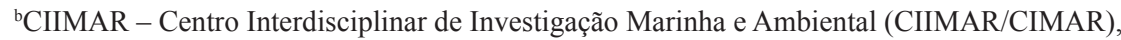 \\ Universidade do Porto, Rua dos Bragas, 289, 4050-123, Porto, Portugal \\ 'Laboratório de Sanidade Aquática, Departamento de Ciências Animais, Universidade Federal Rural do Semi-Árido - \\ UFERSA, BR 110, Km 47, Bairro Presidente Costa e Silva, CEP 59625-900, Mossoró, RN, Brazil \\ *e-mail : jceiras@fc.up.pt
}

Received: November 6, 2012 - Accepted: June 3, 2013 - Distributed: November 30, 2014

(With 1 figures)

\begin{abstract}
The infection of Scomberomorus brasiliensis by the myxozoan Kudoa sp. is reported. The parasites formed plasmodiae inside the skeletal muscle fibres. The spores were quadrate in apical view and bell-like shaped in lateral view, containing four equally sized more or less rounded polar capsules. No detrimental effects were observed in the host, namely muscle liquefaction. The importance of these parasites is discussed.
\end{abstract}

Keywords: fish, Myxosporea, muscle parasites, Kudoa sp., Brazil.

\section{Nota sobre a infeção de Scomberomorus brasiliensis (Osteichthyes, Scombridae) por Kudoa sp. (Myxozoa: Multivalvulida)}

\begin{abstract}
Resumo
Relata-se a parasitose de Scomberomorus brasiliensis pelo myxozoa Kudoa sp. Os parasitas formavam plasmódios no interior das fibras musculares esqueléticas. Os esporos tinham forma quadrada em observação apical e forma de sino achatado em observação lateral, contendo quatro cápsulas polares do mesmo tamanho e sensivelmente arredondas. Não foram observadas lesões nos hospedeiros, nomeadamente liquefacção do músculo. A importância destes parasitas é discutida
\end{abstract}

Palavras-chave: peixes, Myxosporea, parasitas de músculo, Kudoa sp., Brasil.

\section{Introduction}

Kudoa spp. are Multivalvulid Myxozoans with a wide geographical distribution. Moran et al. (1999) provided a review of Kudoa spp. and listed 44 different species, 27 infecting the muscles of the hosts, and 17 locating in other sites of the fish. As well as this, the same authors report a number of non-identified species of the same genus infecting a variety of hosts.

After the review by Moran et al. (1999), 47 new species of Kudoa were described, thereby more than duplicating the number of known species, both from the muscles and other locations within the host, and several occurrences of Kudoa sp. were also notified for several hosts. A few of these species resulted from the inclusion of the other genera of Multivalvulida into the genus Kudoa.

Kudoa spp. may be extremely important from an economical point of view. Some species cause the host muscle liquefaction after the death of the host, rendering the hosts unsuitable for consumption, or diminishing the value of the fish due to the anaesthetical appearance of the muscles due to the presence of conspicuous pseudocysts (for review see Moran et al., 1999). Therefore, the infection by Kudoa sp. can be a detrimental factor both for fisheries and fish culture.

Scomberomorus brasiliensis Collette, Russo \& ZavalaCamin, 1978 (most used common name: Serra), is an important species for Brazilian fisheries. Its geographical distribution includes the entire Brazilian coast, and the high prices reached in the market by the species shows it is an important fishery resource. Therefore, knowledge of the parasites infecting the species is important and may have applied implications if the species is farmed.

In this paper we report for the first time the infection of Scomberomorus brasiliensis by Kudoa sp. 


\section{Material and Methods}

Ten specimens of $S$. brasiliensis (total length: 50.7$57.5 \mathrm{~cm}$ ) were purchased from fishermen near Mossoró, in the state of Rio Grande do Norte. The specimens were placed in ice, transported to the laboratory, and inspected for Kudoa infection. For detecting the parasites a muscle sample was taken in the dorsal region slightly above the lateral line, pressed between two microscope slides and carefully observed under the microscope for detection of plasmodiae. Infected samples were preserved in formalin and examined later since the conditions of observation did not allow the measurement or photographing of the parasites. The other organs of the fish were briefly inspected to detect the presence of the parasites. Twenty five spores were measured according to Burger and Adlard (2010). The eventual myoliquefactive action of the parasites was assessed by visual inspection of the muscle to evaluate the integrity of the muscle fibres, and by palpation of the fish to detect softening of the muscle.

\section{Results}

None of the specimens showed symptoms of myoliquefaction and the texture of the muscle was normal to palpation during a period of 24 hours.

Eight of the ten specimens were infected by Kudoa sp. The parasites formed thin and short plasmodia within the muscle fibres, not visible macroscopically. The intensity of the infection was very small, and a limited number of fibres were infected - only one in about twenty muscle samples examined microscopically was infected. The amount of material sampled did not allow the histological study of the muscle.

The spores (Figure 1) were bell-like shaped in lateral view and stellate, quadrate, in apical view, with four rounded to pyriform equal polar capsules. In apical view the formalin preserved spores measured (in $\mathrm{mm}$ ) 5.5
(4.7-6.7) in width and 4.3 (3.4-5.4) in thickness, and were $4.2(3.7-5.4)$ long in lateral view. The polar capsules were $1.4(1.0-1.7)$ long and $1.1(0.8-1.3)$ in width in apical view, and $1.6(1.0-2.0)$ long and $1.2(1.0-1.3)$ in width in lateral view. The spores corresponded to the type $1 \mathrm{~A} / 1 \mathrm{~B}$ according to the classification of Burger and Adlard (2010).

\section{Discusssion}

Kudoa spp. are common parasites of marine fish and more than ninety different species have been described from different hosts all over the world (see Moran et al., 1999, and subsequent descriptions of species).

In Brazil, there are only a few records of these parasites: $K$. aequidens infecting Aequidens plagiozonatus (Casal et al., 2008), K. sciaenae from Stellifer minor (Oliva et al., 1992), K. crumena from Thunnus albacares (Tavares et al., 2008) and Kudoa sp. in Mugil liza (Amato and Freire, 1989), Trichiurus lepturus (Andrada et al., 2005; Knoff et al., 2002), Plagioscion squamosissimus (Ferreira et al., 2005), and Mugil platanus (Knoff and Serra-Freire, 1993). It is recognised today that molecular studies are essential for the characterisation of new species of Kudoa. From the abovementioned species, only K. crumena was subjected to molecular study. Aequidens plagiozonatus was described by light and transmission electron microscopic observations, and the remaining forms were characterised by light microscopy.

Our observations do not allow the identification of the parasite. The present material was compared with all the descriptions of Kudoa spp. from Brazilian hosts and the morphological and morphometric features do not match with any of them.

We also compared our material with Kudoa species infecting other hosts species belonging to the Scomberomurus genus: K. crumena infecting S. maculatus (Iversen and Van Meter, 1967), K. permulticapsulata from S. commerson (Whipps et al., 2003), and K. scomberomori parasitising
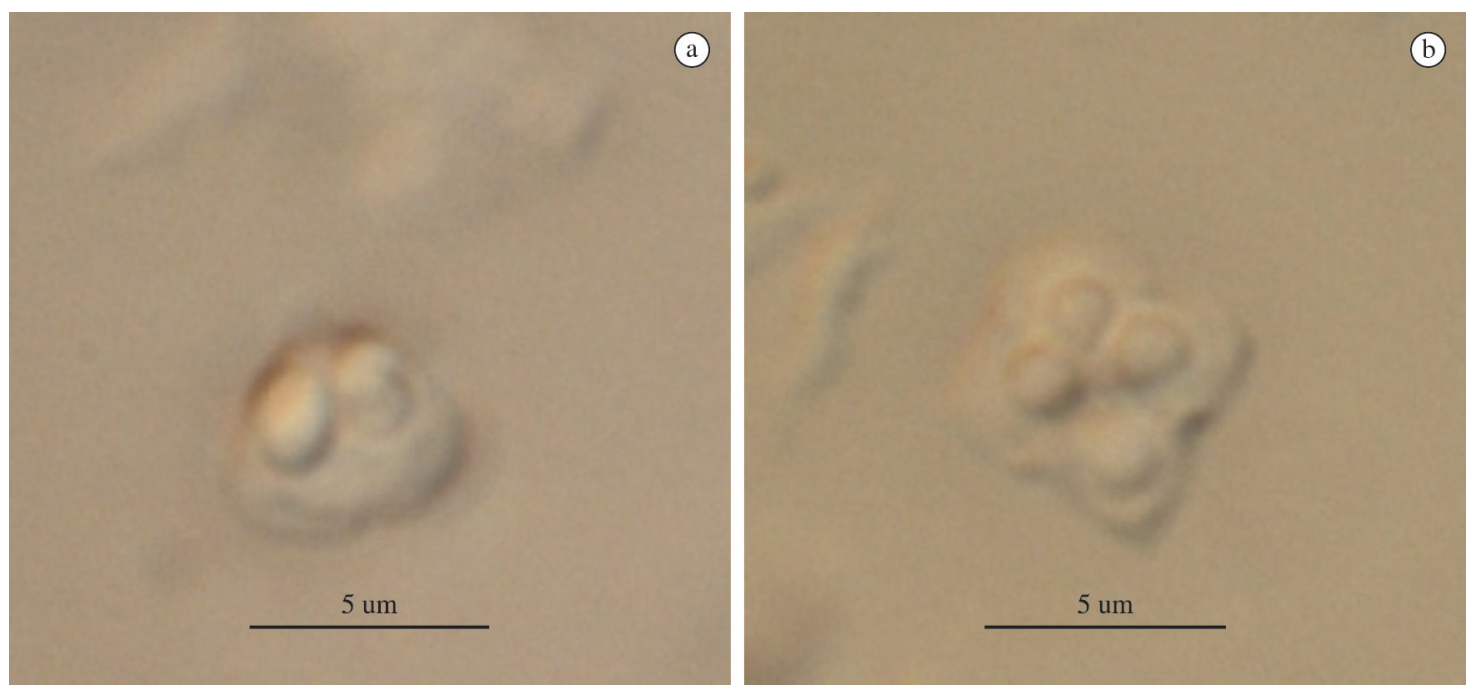

Figure 1. Spores of Kudoa sp. from Scomberomorus brasiliensis observed in lateral (a) and apical view (b). 
S. commerson (Adlard et al., 2005). Kudoa crumena forms more or less round plasmodia located within connective tissue surrounding muscle fibres, and the spores are much larger. Kudoa somberomori has six polar capsules, and $K$. permulticapsula has 13 to 15 polar capsules, a feature which is unique for all the Kudoa species described so far. Therefore, we have to conclude that our material does not belong to the cited species and, due to the inexistence of molecular studies, we do not go further on the identification and comparison with other species.

A number of Kudoa species causes post-mortem myoliquefaction of the muscle of the hosts having a negative impact in aquaculture and fisheries because the hosts lose their commercial value due to the softening of the muscle (for review see Moran et al., 1999). Our specimens did not cause myoliquefaction. Furthermore, all the forms described for Brazilian hosts, and the others infecting Scomberomorus spp. also do not harm the host muscle. Interestingly, the only case of myoliquefaction in Brazil was described by Eiras et al. (2007) in Paralichthys orbygnianus infected by Myxobolus sp., constituting the first description of myoliquefaction originated by this myxozoan genus.

The number of Kudoa species described for Brazilian fish is very small taking into account the great fish diversity. It is postulated that a great number of species exists, some eventually causing myoliquefaction with impact in the exploitation of the host species. A study of these parasites in Brazil hosts, including its molecular characterisation, is currently being carried out.

\section{Acknowledgements}

Participation of J.C.Eiras, C. F. Cruz and A. Saraiva in this research was partially supported by the European Regional Development Fund (ERDF) through the COMPETE Operational Competitiveness Programme, and national funds through FCT - Foundation for Science and Technology, under the project "PEst-C/MAR/LA0015/2011".

\section{References}

ADLARD, RD., BRYANT, MS., WHIPPS, CM. and KENT, ML., 2005. Multivalvulid myxozoans from eastern Australia: three new species of Kudoa from scombrid and labrid fishes of the Great Barrier Reef, Queensland, Australia. Journal of Parasitology, vol. 91, no. 5, p. 1138-1142. http://dx.doi.org/10.1645/GE-368R.1. PMid:16419761

AMATO, FFR. and FREIRE, NMS., 1989. Protozoários parasitas de Mugil Liza Valenciennes, 1836 do litoral do Estado do Rio de Janeiro. In Anais do XI Congresso Brasileiro de Parasitologia, 1989. Rio de Janeiro. Rio de Janeiro. p. 122

ANDRADA, CG., TORTELLY, R., NOGUEIRA, PP., ANDRADE, CL. and LIMA, FC., 2005. Infecção por Kudoa Meglitsch, 1947 (Myxozoa: Multivalvulida) em musculatura esquelética de espada Trichiurus lepturos L. (Teleostei: Trichiuridae). Parasitologia Latinoamericana, vol. 60, no. 3-4, p. 150-153.
BURGER, MA. and ADLARD, RD., 2010. Four new species of KudoaMeglitsch, 1947 (Myxosporea: Multivalvulida) from Australia with recommendations for species descriptions in the Kudoidae. Parasitology, vol. 137, no. 5, p. 793-814. http://dx.doi. org/10.1017/S0031182009991557. PMid:20025820

CASAL, G., MATOS, E., MATOS, P. and AZEVEDO, C., 2008. Ultrastructural description of a new myxosporean parasite Kudoa aequidens sp. n. (Myxozoa, Myxosporea), found in the sub-opercular musculature of Aequidens plagiozonatus (Teleostei) from the Amazon River. Acta Protozoologica, vol. 47, no. 2, p. 135-141.

EIRAS, JC., JÚNIOR, JP., SAMPAIO, LA., ROBALDO, R. and ABREU, PC., 2007. Myxobolus sp. can cause myoliquefaction in vivo in the host Paralichthys orbignyanus Valenciennes, 1893 (Osteichthyes, Paralichthydae). Diseases of Aquatic Organisms, vol. 77, no. 3, p. 255-258. PMid:18062475.

FERREIRA, ES., HOLANDA, WRS., SEIXAS, LS., MATOS, P. and MATOS, E., 2005. Ocorrência de Kudoa sp. em Plagioscion squamosissimus (Heckel, 1840) no Estado do Pará. In Anais do XIV Congresso Brasileiro de Engenharia de Pesca, 2005. Fortaleza. Fortaleza. p. 89.

IVERSEN, ES. and VAN METER, NN., 1967. A new myxosporidian (Sporozoa) infecting the Spanish mackerel. Bulletin of Marine Science, vol. 172, no. 2, p. 268-273.

KNOFF, M. and SERRA-FREIRE, NM., 1993. Protozoários parasitos de Mugil platanus Günther, 1880 do litoral do Estado do Rio de Janeiro, Brasil. Revista Brasileira de Parasitologia Veterinária, vol. 2, no. 1, p. 25-28.

KNOFF, M., SÃO CLEMENTE, SC., LIMA, FC., PINTO, RM. and GOMES, DC., 2002. Infecção por Kudoa, Meglitsch, 1947 (Myxozoa: Multivalvulida) em musculatura esquelética de espada Trichiurus lepturus L. (Teleostei: Trichiuridae). In Anais do VII Encontro Brasileiro de Patologistas de Organismos Aquáticos, 2002. Foz do Iguaçú. Foz do Iguaçú. p. 157.

MORAN, JDW., WHITAKER, DJ. and KENT, ML., 1999. A review of the myxosporean genus Kudoa Meglitsch, 1947, and its impact on the international industry and commercial fisheries. Aquaculture (Amsterdam, Netherlands), vol. 17, no. 2, p. 163-196.

OLIVA, M., LUQUE, JL., TERAN, L. and LLICAN, L., 1992. Kudoa sciaenae (Myxozoa: Multivalvulidae) cysts distribution in the somatic muscles of Stellifer minor (Tschudi, 1844) (Pisces: Sciaenidae). Memorias do Instituto Oswaldo Cruz, vol. 87, no. 1, p. 33-35. http://dx.doi.org/10.1590/S0074-02761992000100006.

TAVARES, LER., LUQUE, JL., ELISEI, C., SOARES, CO., ARAÚJO, FR., ROSINHA, GMS., SANCHES, CC. and PERDIGÃO, SF., 2008. Ocorrência de Kudoa crumena (Myxozoa: Myxosporea) parasitando Thunnus albacares (Perciformes: Scombridae) no litoral do Estado de São Paulo, Brasil. In Anais do X Encontro Brasileiro de Patologistas de Organismos Aquáticos. 2008. Búzios. Búzios. p. 185.

WHIPPS, CM., ADLARD, RD., BRYANT, MS. and KENT, ML., 2003. Two unusual myxozoans, Kudoa quadricornis n. sp. (Multivalvulida) from the muscle of goldspotted trevally (Carangoides fulvoguttatus) and Kudoa permulticapsula n. sp. (Multivalvulida) from the muscle of Spanish mackerel (Scomberomorus commerson) from the Great Barrier Reef, Australia. The Journal of Parasitology, vol. 89, no. 1, p. 168-173. http://dx.doi.org/10.1645/0022-3395(2003)089[0168:TUMKQN ]2.0.CO;2. PMid: 12659322 